\title{
RECENT DEVELOPMENTS UNDER THE BRUSSELS I REGULATION
}

Abstract This article considers recent CJEU case law on the Brussels I Regulation. Two aspects of Article 7(1) (which applies to matters relating to a contract) are considered: the first is whether the contract must be between the parties to the case; the second is whether membership of an association should be regarded as constituting implied consent to be bound by decisions of the association so that jurisdiction to enforce them may be taken under Article $7(1)$. The article also discusses recent case law on who counts as a 'consumer' in terms of Article 17.

Key words: Brussels I Regulation, claims in contract, members of an association, consumers.

\section{MATTERS RELATING TO A CONTRACT}

Article 7(1) of Brussels 2012 lays down jurisdictional rules which apply 'in matters relating to a contract'. It provides that the courts for the place of performance of the obligation in question have jurisdiction. ${ }^{1}$ In order to decide whether this ground of jurisdiction applies in a given case, one must first decide whether the action concerns a matter 'relating to a contract'. This seemingly simple phrase gives rise to a host of issues. In this article, we will consider two. The first is: who must the contract be between? Must it be between the parties to the case or is it sufficient if it is between other persons?

\section{A. Contract Between Whom?}

In Handte v. TMCS, ${ }^{2}$ the CJEU said that what is now Brussels 2012, Article 7(1) (then Article 5(1) of the Brussels Convention) does not apply if there is no obligation freely assumed by one party towards another. Until recently, it was generally assumed that this meant that the contract must be between the parties to the case. The claim in Handte arose when a German manufacturer (Handte Germany) sold a product to a French company (Handte France), ${ }^{3}$ and the latter resold it to another French company, TMCS. The product was defective ${ }^{4}$ and TMCS sued the manufacturer in France. The action was in contract, not tort. Did what is now Article 7(1) of Brussels 2012 give jurisdiction to the French courts? ${ }^{5}$ There was a contract between the manufacturer and Handte France; and there was another contract between Handte France and TMCS. However, there was no contract between TMCS and the manufacturer. As a matter of substantive French law, the claim in these circumstances could be brought in contract, apparently on the basis of an implied assignment: Handte France was deemed to have assigned its rights against the

\footnotetext{
${ }^{1}$ Article 7(1)(b) goes on to lay down rules for determining where the place of performance is.

2 Case C-26/91, [1992] ECR I-3967 34.

${ }^{3}$ Handte France appeared to be the subsidiary of Handte Germany, but this was not certain.

${ }^{4}$ It was said that it did not comply with the rules on hygiene and safety at work and was unfit for its purpose.

${ }^{5}$ This was not the only provision on which the French courts might have obtained jurisdiction. As was pointed out by Advocate General Jacobs in paragraph 5 of his Opinion, there were several other provisions which might, depending on the facts, have been applicable. These were Article 5(3) of the Brussels Convention (matters relating to tort), Article 5(5) of the Convention (branch, agency, or other establishment: Handte France was also a party to the proceedings), Article 6(1) (multiple defendants) and Article 6(2) (third-party proceedings).
} 
manufacturer to TMCS. ${ }^{6}$ However, this rule of French law did not answer the jurisdictional question because the meaning of provisions in what was then the Brussels Convention, and is now Brussels 2012, cannot depend on national law.

After saying that what is now Article 7(1) of Brussels 2012, 'is not to be understood as covering a situation in which there is no obligation freely assumed by one party towards another', ${ }^{7}$ and pointing out that in a situation such as that in the case, the manufacturer has no contractual relationship with the sub-buyer and undertakes no contractual obligation towards that buyer, ${ }^{8}$ the CJEU ruled that what is now Article 7(1) of Brussels 2012 does not apply to an action between a sub-buyer of goods and the manufacturer, who is not the seller, relating to defects in those goods or to their unsuitability for their intended purpose. ${ }^{9}$ In these circumstances, it is hard to see how the 'obligation freely assumed' can be anything other than an obligation assumed by one of the parties to the case towards the other.

Recent cases, however, show that this is not so. The first is Kareda. ${ }^{10}$ This concerned a couple who obtained a loan from an Austrian bank to buy a house in Austria. Under the loan agreement, they were jointly and severally liable. After a time, their relationship broke down and the woman returned to her home country, Estonia. Thereafter, the man paid all the instalments as they became due. Subsequently, he sued her in Austria for her share of the debt. He said that the Austrian courts had jurisdiction under Article 7(1) of Brussels 2012. While it is clear that each of them had a contract with the bank, it might be thought that there was no contract between the two of them. The CJEU, however, held that the claim did relate to a contract in terms of Article 7(1), thus suggesting that the freely consented obligation need not be between the parties to the claim, but may be between each of them and a third person. ${ }^{11}$

The next case was flightright, ${ }^{12}$ a case under an EU Regulation ${ }^{13}$ giving passengers on commercial airlines the right to compensation if the flight is late. The case concerned a situation which can arise quite often: the passenger wants to fly from $A$ to $B$, but to do so, he has to go first from $A$ to $X$ and then from $X$ to $B$. The two flights may be on different airlines; nevertheless, it is often possible to obtain a single ticket from one carrier, known as the 'contractual air carrier' ('CAC'), which also covers the leg operated by the other carrier, known as the 'operating air carrier' ('OAC'). In this situation, the passenger has a contract

\footnotetext{
${ }^{6}$ A similar rule also applied in the law of Belgium and of Luxembourg. For a discussion of the law of France, Belgium and Luxembourg, see per Advocate General Jacobs at paragraph 20 of his Opinion: ECLI:EU:C:1992:176.

7 Paragraph 15 of the judgment.

8 Paragraph 20 of the judgment.

9 Paragraph 21 of the judgment.

10 Case C-249/16, ECLI:EU:C:2017:472.

${ }^{11}$ Advocate General Bot took the view that the rights inter se of the two debtors were inseparable from the relationship between the debtors and the creditor. He also pointed out that under Article 16 of Rome I, if a creditor has a claim against several debtors who are liable for the same claim, and one of the debtors has already satisfied the claim, the law governing the debtor's obligation towards the creditor also governs the debtor's right to claim recourse from the other debtors. The CJEU took up this point in paragraph 32 of the judgment.

12 Joined Cases C-274/16, C-447/16 and C-448/16, ECLI:EU:C:2018:160.

13 Regulation 261/2004.
} 
with the CAC but not with the OAC, though the CAC will have a contract with the OAC. If the $\mathrm{OAC}$ is the one at fault and the passenger sues it (as he is entitled to do under the Regulation), is the claim a matter 'relating to a contract'? The CJEU said it was. It said that Article 7(1) of Brussels 2012 'is based on the cause of action, not the identity of the parties'. ${ }^{14}$ Since the OAC is regarded as fulfilling the obligations of the CAC towards the passenger, ${ }^{15}$ the passenger's claim relates to a contract in terms of Article $7(1)$.

In Králová v. Primera Air Scandinavia ${ }^{16}$ the same principle was applied to a package holiday in which the traveller had a contract with a travel agent but not with the airline. The flight was delayed and the passenger sued the airline. The CJEU held that the claim was covered by Article 7(1).

This was followed by Feniks, ${ }^{17}$ which concerned an actio pauliana. This is an action, derived from Roman law, which is found in many Continental legal systems. It is brought when a debtor transfers his property to a third party to fraudulently deprive the creditor of his rights. Under it, the creditor can sue the third party for a declaration that the transfer is not valid against the creditor. He can then recover the debt out of the property in question. The question in the case was whether the court can obtain jurisdiction in the creditor's action against the third party under what is now Article 7(1) of Brussels 2012. The CJEU said that it could. The relevant contract would be the contract between the debtor and the creditor under which the debt arose. The action against the third party can then be brought in the courts for the place of performance of that contract, even though the defendant in the action (the third party) was not a party to that contract.

The last case to consider is Reitbauer, ${ }^{18}$ which concerned a claim which was similar to an actio pauliana. A woman domiciled in Italy owned a house in Austria. She hired a contractor to renovate the house but did not pay him. She then executed a charge over the house in favour of a man domiciled in Italy with whom she had previously been living. This was to secure a debt which she allegedly owed him. The contractor who had worked on the house subsequently registered another charge over the house to secure his claim. When the house was sold, the money it fetched was barely enough to cover the first charge (which had priority); so there was almost nothing left for the contractor. The contractor then brought proceedings in the nature of an actio pauliana to have the first charge set aside as being in fraud of his claim. The CJEU again held that the actio pauliana was covered by Article 7(1) of Brussels 2012. The relevant contract was that between the woman and the contractor to renovate the house. Since the place of performance of that contract was Austria, the Austrian courts had jurisdiction to hear the actio pauliana.

In these recent cases, the crucial point is the statement made by the CJEU that Article 7(1) of Brussels 2012 is based on the cause of action, not the identity of the parties. ${ }^{19}$ This seems

\footnotetext{
14 Paragraph 61 of the judgment in flightright, citing paragraphs 31 and 33 of the judgment in Kareda.

15 Regulation 261/2004, Article 3(5), second sentence.

16 Case C-215/18, ECLI:EU:C:2020:235.

17 Case C-337/17, ECLI:EU:C:2018:805.

18 Case C-722/17, ECLI:EU:C:2019:577.

19 Paragraph 61 of the judgment in flightright, citing paragraphs 31 and 33 of the judgment in Kareda.
} 
to mean that if the cause of action is a matter relating to a contract, it does not matter if the parties to the case are not the same as the parties to the contract. The Handte decision might seem hard to reconcile with this principle. The claim in that case was brought in contract. It was based on two contracts, one between the claimant (TMCS) and Handte France, and one between Handte France and the defendant (the manufacturer). If what matters is the cause of action, not the identity of the parties, why was the case not covered by what is now Article 7(1)?

The fact that in this situation a claim in contract is not possible under most legal systems may have been the determining factor. ${ }^{20}$ It is usually said that the characterization of a claim for jurisdictional purposes should be based on a uniform European rule, not on its characterization under national law. ${ }^{21}$ If this were done, the claim in the Handte situation would probably be regarded as being in tort, since in most legal systems a claim against a manufacturer when there is no direct contract between it and the claimant can be brought, if at all, only in tort. It would then come under Brussels 2012, Article 7(2), not Article 7(1). All the CJEU decided in Handte was that what is now Article 7(1) does not apply to an action between a sub-buyer of goods and the manufacturer, who is not the seller, relating to defects in those goods or to their unsuitability for their intended purpose. If the true ground of the decision is that the claim concerned a matter relating to tort, not a matter relating to a contract, ${ }^{22}$ the judgment can be reconciled with the cases discussed previously.

If the claim were to be characterized, for jurisdictional purposes, ${ }^{23}$ as coming under Article $7(2)$, the next question would be: what should constitute the 'harmful event' and where should it be regarded as having occurred? It seems that in Handte the product did not cause physical harm to any person or property; so under many legal systems there would have been no tort at all. Under French law, the position was different. Advocate General Jacobs thought that, if there was no physical harm, the harmful event should be regarded as the delivery of the goods to the first purchaser (Handte France, in the case). If, on the other hand, there was physical harm, it should be the place where that harm occurred. This would usually be the place where the sub-purchaser (TMCS, in the case) used the product. ${ }^{24}$

\footnotetext{
20 See paragraph 10 of the judgment in Handte.

${ }^{21}$ See per Advocate General Jacobs at paragraph 22 of his Opinion, citing Case 9/87, Arcado v. Haviland [1988] ECR 1539, at paragraphs 10 and 11 of the judgment.

22 In Advocate General Jacobs' view, this was the essential issue in the case: see paragraphs 6 et seq. of his Opinion.

23 The characterization of a claim for jurisdictional purposes does not affect the basis on which it will be decided as a matter of substantive law. As Advocate General Jacobs said at paragraph 24 of his Opinion: 'A court that acquires jurisdiction under Article 5(1) [now Article 7(1)] is not prevented by the Convention from proceeding with the action on the basis that it is delictual and a court that acquires jurisdiction under Article 5(3) [now Article 7(2)] is not prevented by the Convention from proceeding with the action on the basis that it is contractual.' However, if it does proceed on the basis that the claim is contractual, the question of choice of law arises. It is not clear whether a claim in contract can be successful in the Handte situation unless both contracts are governed by a system of law that adopts the French solution. On the facts of Handte, the contract between Handte Germany and Handte France would today be governed by German law unless there was a choice-of-law clause: Rome I, Article 4(1)(a). German law does not adopt the French solution.

24 See paragraphs 25-39 of the Opinion.
} 
The recent case of Verein für Konsumenteninformation v. Volkswagen $A G,{ }^{25}$ however, suggests a different solution. This case arose out of the scandal when Volkswagen installed special software in some of its cars so as to produce misleading results when they were tested for exhaust gas emissions. It was only through this manoeuvre that Volkswagen was able to obtain type approval for vehicles with its EA 189 engine. This was unlawful under EU law.

The Verein für Konsumenteninformation (the 'VKI') was an Austrian consumer organization. Over 500 Austrian motorists who had bought the cars in question had assigned their claims for compensation to the VKI. It sued Volkswagen in tort in an Austrian court. It claimed that the damage consisted in the fact that, had they been aware of the manipulation, the motorists would either not have purchased the vehicles or would have purchased them at a price reduced by at least 30 per cent. Since the vehicles were defective from the outset, their market value, and therefore their purchase price, were significantly lower than the purchase price actually paid. The VKI argued that the difference constituted a recoverable loss.

The question before the CJEU was whether the Austrian court had jurisdiction against Volkswagen, a German company, under Article 7(2) of Brussels 2012. Since the motorists had not bought their cars directly from Volkswagen-they had either bought them from Austrian dealers supplied by Volkswagen or had bought them second-hand from the original purchasers-the case was similar to Handte. Did the harmful event occur in Austria?

The CJEU held that it did. It said that the installation of the software by Volkswagen constituted the causal act. This occurred in Germany. However, the actual damage occurred when the purchasers bought their cars in Austria: this was not mere consequential loss, not to be taken into account under the CJEU's decision in Marinari. ${ }^{26}$ The CJEU said: ${ }^{27}$

Such damage, which did not exist before the purchase of the vehicle by the final purchaser who considers himself adversely affected, constitutes initial damage ... and not an indirect consequence of the harm initially suffered by other persons...

The CJEU went on to hold, rather surprisingly, that this was not pure financial damage. ${ }^{28}$ It said that, unlike in the cases on investment loss, ${ }^{29}$ it concerned a defect in a tangible asset, a car. ${ }^{30}$ It therefore concluded that the claim was for material damage 'resulting from a loss in value of each vehicle concerned and stemming from the fact that, with the disclosure that software which manipulates data relating to exhaust gas emissions was installed, the purchaser received, in return for the payment made to purchase such a vehicle, a vehicle which is defective and, accordingly, has a lower value. ${ }^{31}$

\footnotetext{
25 Case C-343/19, ECLI:EU:C:2020:534.

26 Case C-364/93, EU:C:1995:289.

27 At paragraph 31 of the judgment.

28 Paragraph 32 of the judgment.

${ }^{29}$ Kronhofer, Case C-168/02, EU:C:2004:364; Kolassa Case C-375/13, EU:C:2015:37; and Löber Case C-304/17, EU:C:2018:701.

30 Paragraph 33 of the judgment.

31 Paragraph 34 of the judgment.
} 
If we transpose this reasoning to the Handte case viewed as a claim in tort, it could be argued that TMCS's loss consisted in the fact that the product did not comply with the rules on hygiene and safety at work and was unfit for its purpose. One assumes that TMCS would not have bought the product if it had known this. On the reasoning of the Volkswagen case, this was direct (not consequential) loss which occurred only when the product was bought by TMCS. It would seem that the place of the damage was the place where the product was delivered to TMCS. We shall have to see whether this reasoning is accepted if the question ever comes before the CJEU.

\section{B. What Constitutes Agreement?}

The next question to consider is: what constitutes agreement to the contract? This question can arise where the defendant is a member of an association, and the association takes a decision imposing an obligation-usually financial-on its members. Can proceedings to enforce the obligation be brought under Brussels 2012, Article 7(1), even if the defendant opposed the decision?

Kerr v. Postnov and Postnova ${ }^{32}$ concerned relations among co-owners of flats in a block of flats in Bulgaria. Under Bulgarian law, the association of owners (which did not have legal personality) could adopt resolutions in a general meeting, imposing contributions on the individual owners for the maintenance of communal areas. A number of such resolutions had been adopted, but two coowners, Mr Postnov and Ms Postnova, who were domiciled in Ireland, had not paid. Mr Kerr, who was the manager of the property, brought proceedings against them in a court in Bulgaria. The question before the CJEU was whether the Bulgarian court had jurisdiction under Article 7(1) of Brussels 2012.

The CJEU held that it did. It reached this conclusion in two steps. First, it held on the basis of a line of earlier cases that, for Article 7(1) to apply, it is not necessary for there to be a contract, as long as there is a legal obligation freely consented to by one person towards another that forms the basis of the claimant's action. ${ }^{33}$ It then referred to an older line of cases that established that obligations relating to the payment of a sum of money which have their basis in the relationship between an association and its members must be regarded as 'matters relating to a contract' within the meaning of what is now Article 7(1), on the ground that membership of an association creates between the members close links of the same kind as those which are created between the parties to a contract. ${ }^{34}$

It made no difference, the CJEU held, that owners of the property in Kerr v. Postnov and Postnova automatically became members of the association and that some may not have taken part in the adopting of the decision, or may have opposed it. By becoming and remaining the owner of a property in a building, each owner agreed to be subject to all the provisions in the act governing the association of property owners and the decisions adopted by the general meeting of the owners. ${ }^{35}$ This was sufficient to give rise to an obligation freely consented to by the defendants.

\footnotetext{
32 Case C-25/18, ECLI:EU:C:2019:376.

33 Česká spořitelna, Case C-419/11, EU:C:2013:165, at paragraphs 46 and 47; Kolassa, Case C-375/13, EU:C:2015:37, at paragraph 39; ÖFAB, Case C-147/12, EU:C:2013:490, at paragraph 33; and Austro-Mechana, Case C-572/14, EU:C:2016:286, at paragraphs 35 and 36).

34 Peters Bauunternehmung, Case 34/82, EU:C:1983:87, at paragraphs 13 and 15; Powell Duffryn, Case C-214/89, EU:C:1992:115, at paragraph 15; and Engler, Case C-27/02, EU:C:2005:33, at paragraph 47.

35 Paragraph 29 of the judgment in Kerr.
} 
A slightly more difficult question came before the CJEU in Ordre des avocats du barreau de Dinant $v$. $J N .{ }^{28}$ The claimant in this case was a local bar association in Belgium, the Dinant Bar Association. In Belgium, there appear to be a number of local bar associations, and membership of such an association is obligatory for anyone wanting to practise law. The local bar associations have the power to require their members to pay dues. The money raised is mainly for the purpose of providing insurance coverage for the members. JN was a Belgian avocat (barrister), who was a member of the Dinant Bar Association, but was domiciled in France. He had not paid his dues and the Dinant Bar Association brought proceedings before a court in Belgium. The court asked the CJEU whether it had jurisdiction under Article 7(1) of Brussels 2012

It seems that all the bar associations in the French-speaking part of Belgium, together with the small German-speaking part, were members of a wider organization, the Association of the Frenchspeaking and German-speaking Bars, which was a legal person governed by public law. Bar associations were not concerned only with protecting the interests of their members. According to the Advocate General, they also had a duty to the general public to guarantee the integrity and experience of lawyers and to ensure the sound administration of justice. ${ }^{36}$ These facts made it more difficult to regard the relationship between a local bar association and its members as purely contractual.

For this reason, the CJEU-although it adopted the same analysis as in the previous case-said that the Belgian court would have jurisdiction only if two conditions were fulfilled. First, the bar association must not have been acting in the exercise of public powers in imposing the dues. If it were, the proceedings would fall outside the subject-matter scope of the Regulation. Secondly, the dues must constitute consideration for services provided by the bar association to its members and those services must have been freely consented to by the member concerned. In both cases, the national court was to decide whether these conditions were met.

It is not unreasonable in principle to say that if an association imposes an obligation on its members, they should be regarded as having consented to it by virtue of the fact that they voluntarily joined the association and remained a member after it had imposed the obligation. However, if taken too far, this idea can produce ridiculous results. One cannot say, for example, that, by living and working in a country, a taxpayer consents to pay income tax, thus making an action for the recovery of tax a matter falling under Article 7(1). It was probably to avoid such a result that the CJEU imposed these two conditions.

\section{WHO COUNTS AS A CONSUMER UNDER THE BRUSSELS I REGULATION?}

The Brussels I Regulation, in common with other EU and national measures, regards consumers as being in need of special protection when they conclude contracts with business people. Consumers are at a disadvantage in such a situation: they lack bargaining power and experience. In the field of jurisdiction, for example, the contract will often contain a choice-of-court clause giving exclusive jurisdiction to a court in a distant country whose language the consumer does not understand. In practice, this often means that the consumer has no legal remedy if there is a problem with the goods or services supplied. The idea that competition will solve these problems has proved false: if the consumer goes to a different supplier, he will find that the contractual terms are just the same.

\footnotetext{
${ }^{36}$ Paragraph 34 of the Opinion: ECLI:EU:C:2019:86.
} 
The solution of Brussels I is to lay down special jurisdictional rules, which are deliberately skewed in favour of the consumer. They apply to contracts ${ }^{37}$ concluded by a consumer when the contract is: ${ }^{38}$

(a) for the sale of goods on instalment credit terms;

(b) for a loan repayable by instalments, or for any other form of credit, made to finance the sale of goods; or

(c) in all other contracts, if the supplier has in some way targeted the Member State of the consumer's domicile. ${ }^{39}$

Only one kind of contract is expressly excluded: transport contracts other than package trips. ${ }^{40}$ In all cases, the other person must be a non-consumer (a person acting in the course of his trade or profession): a contract between two consumers is not covered. ${ }^{41}$

The special jurisdictional rules may be summarized as follows:

- If the consumer sues the supplier, he can bring the action in either his own domicile or in that of the supplier; ${ }^{42}$

- On the other hand, if the supplier sues the consumer, the action must be brought in the consumer's domicile; 43

- These rules cannot be altered by a choice-of-court agreement, except in certain specified instances in which it is considered that the consumer will not be prejudiced. ${ }^{44}$

It will be seen that these rules put the consumer in a good position. However, in order to benefit from them, he must establish that he is a consumer.

Who exactly counts as a consumer under the Regulation? The definition, given in Brussels 2012, Article 17(1) is simple but rather uninformative: a consumer is a person who concludes the contract 'for a purpose which can be regarded as being outside his trade or profession'. This is in essence a negative definition: everyone is a consumer unless he is acting in the course of his trade or profession. The other party, however, must be acting in the course of his trade or profession. If he is not he will also constitute a consumer and, as explained above, a contract between two consumers does not benefit from the special jurisdictional rules.

\footnotetext{
37 Although the rules apply in principle only to claims in contract, they can also apply to claims in tort if the claim in tort is indissociably linked to a contract concluded between the consumer and the seller or supplier: AU v. Reliantco Investments, Case C-500/18, ECLI:EU:C:2020:264.

38 Brussels 2012, Article 17(1).

${ }^{39}$ What this entails is spelled out in more detail in the Regulation.

40 Brussels 2012, Article 17(3).

41 The text does not expressly say this, but it is generally accepted to be the case: See per Advocate General Capotorti in Bertrand v. Ott, Case C-150/77, ECLI:EU:C:1978:116, [1978] ECR 1431 at p. 1450.

42 Brussels 2012, Article 18(1).

43 Brussels 2012, Article 18(2).

${ }^{44}$ Brussels 2012, Article 19.
} 
It follows from this that, in order to decide whether a person is acting as a consumer, one must first decide what his trade or profession is (assuming that he has one). Then one must decide what the purpose is for which he concluded the contract: was it for his trade or profession?

What constitutes a trade or profession (business) is the more difficult question. It might be thought that it all depends on whether the activity is intended to produce an income, but a moment's thought shows that things are not so simple. A retired person who invests money to produce an income for his retirement is clearly a consumer. This is so irrespective of whether he puts his money in a building society, buys an annuity, or invests in a fund of some sort. What if he plays an active role in the investment, making vital investment decisions himself? This is what happened in a recent case, Petruchová..$^{45}$

In this case, the claimant, Ms Petruchová, was a university student in the Czech Republic. She concluded a contract with the defendant, a brokerage company incorporated in Cyprus, which enabled her to trade on the FOREX (foreign exchange) market, concluding financial contracts for differences. This was not her main activity. In addition to her university studies, she had a part-time job, but this was apparently unconnected with her FOREX trading.

Various arguments were advanced as to why she should not be regarded as a consumer. One was that she took the vital decisions: she chose which markets to trade and when to enter and exit a position. This was possible only because she had some knowledge of the FOREX market, knowledge gained when she had previously worked in the financial sector.

Did her specialist knowledge make her a professional? Since one of the arguments put forward for the policy of giving consumers special protection is their lack of specialist expertise, one might think that it would. However, a person whose hobby is fly fishing or bird watching might have great knowledge in that area, but this would not prevent him from being a consumer when buying equipment from a supplier of such things. The same would be true of an artist: he might have extensive knowledge of artistic techniques, including the different kinds of paint and how each should be used, but this would not mean that he was not a consumer if his painting was only a hobby. The question whether it was a hobby or a profession would not depend on the level of his knowledge.

It might be thought that someone trading on a financial market was in a different position, but Ms Petruchová was not suing the defendant because she had relied on its specialist knowledge and it had failed her: she was suing it because it had not executed her order on time. ${ }^{46}$ For these reasons, the CJEU held that it was not relevant that she had specialist knowledge or that she used it to take vital trading decisions herself.

The CJEU also held that it was irrelevant that the sums of money involved were large (she borrowed money from the defendant to make each trade and repaid it afterwards) or that

\footnotetext{
45 Case C-208/18, ECLI:EU:C:2019:825. See also AU v. Reliantco Investments, Case C-500/18, ECLI:EU:C:2020:264.

46 The trade was only executed 16 seconds late but, in the FOREX market, 16 seconds is a long time.
} 
there were considerable risks involved. The issue, said the court, was simply whether the particular contract in question did or did not fall within the scope of her professional activity. This was a matter for the Czech court to determine. It is, however, interesting that Advocate General Tanchev, whose Opinion ${ }^{47}$ was followed by the CJEU, considered that Ms Petruchová was a consumer in relation to the transaction in question.

Another recent case, Milivojević, ${ }^{48}$ throws further light on the matter. Ms Milivojević was a Croatian lady who owned a house in Croatia which was her residence. She borrowed money from an Austrian bank to carry out extensive renovation work on it, in order to create flats for rent; however, she kept open the possibility that she might use some of the money for private purposes. Was she a consumer with regard to the loan from the bank?

The CJEU first pointed out that a person does not constitute a consumer if the contract is for the purpose of trade or professional activity, even if that activity is only planned for the future. ${ }^{49}$ Secondly, a person who concludes a contract for a dual purpose, partly for use in his professional activity and partly for private matters, is to be considered a consumer with regard to that contract only if the link between the contract and the person's trade or profession is so slight as to be marginal and, therefore, had only a negligible role with regard to the contract. ${ }^{50}$ As a result, the CJEU held that Ms Milivojević could be considered to have concluded the agreement as a consumer only if the link between that contract and the professional activity in the form of tourist accommodation services was so marginal and negligible that the contract was concluded essentially for private purposes.

What is notable about several recent cases is that the CJEU has been forthright in rejecting any short-cut tests that could provide an easy answer. We have already seen that specialist knowledge used to take strategic decisions is not relevant, nor is the amount of money involved and the level of risk..$^{51}$ Other tests that have been rejected are whether the contract in question is covered by the consumer-protection provisions of the Rome I Regulation; ${ }^{52}$ and whether the person claiming to be a consumer is a 'retail client' under Directive 2004/39 on markets in financial instruments. ${ }^{53}$ In another case, the CJEU held it was irrelevant, in deciding whether a person who had taken out a loan was a consumer, that the loan was not covered by Directive 2008/48 EC on consumer credit agreements. ${ }^{54}$ It seems that the CJEU is intent on ensuring that the test laid down in Brussels I itself is applied as it is, without any dilution or garnish.

\footnotetext{
47 ECLI:EU:C:2019:3140.

48 C-630/17, ECLI:EU:C:2019:123.

49 This had already been established in the earlier case of Benincasa, C-269/95, EU:C:1997:337, paragraph 17 of the judgment.

50 This had also been established in an earlier case: Schrems, C-498/16, EU:C:2018:37, paragraph 32.

51 Petruchová, C-208/18, ECLI:EU:C:2019:825

52 In Rome I (Regulation 593/2008), the definition of a consumer, set out in Article 6(1), is very similar to that in Brussels I; however, a number of specific types of contract are expressly excluded, one of which concerns financial instruments: see Rome I, Article $6(4)(d)$. This would have covered the contracts concluded by Ms Petruchová.

53 Petruchová (supra).

54 Pillar Securitisation, Case C-694/17, ECLI:EU:C:2019:345.
} 
However, though it is useful to identify false leads so that one can focus on what is relevant, the question still remains: when is an activity to be regarded as being a trade or profession? There is no doubt that, for some people, trading on the FOREX market is their profession: how is one to distinguish such people from those who are not carrying out a trade or profession?

It is not known how Ms Petruchová supported herself and what her income was. Would it be relevant to know to what extent her FOREX activities contributed to it? If, for example she was supported by her parents and the money she made through trading was something she could easily do without, would that make her a consumer? If, on the other hand, most or all of her income came from her trading, would that mean she was a professional? This possibility was considered by Advocate General Tanchev and, rather surprisingly, he rejected the idea that a person should lose the status of a consumer if the profit made on the FOREX market accounted for the largest part of his income. ${ }^{55} \mathrm{His}$ argument was that such an approach could give unfair advantages to rich people: if a millionaire and a middleclass investor place an order for the same amount on the FOREX market, and they make the same profit, the former might be regarded as a consumer and the latter might not. The CJEU did not give a view on this point, since it was not one of the questions asked by the Czech court; so the possibility may still be open that this is an appropriate way to proceed. It is hard to see how, in cases like Petruchová, an activity that provides all or most of a person's income could, assuming that he has no other means of support, be anything other than his trade or profession. For this reason, one may doubt the correctness of the Advocate General's rejection of this criterion.

Finally, it is interesting to note that the general policy of the CJEU seems to be to leave it to the national court to make the final decision. As long as it applies the right test, its decision will probably be respected. This could give the national court a significant margin of discretion.

${ }^{55}$ ECLI:EU:C:2019:3140 at paragraph 52. 